УДК 656.07:656.6

JEL L91, O21, R42

DOI 10.31375/2226-1915-2020-4-19-30

НАБЛИЖЕННЯ

\section{ДО МОДЕЛІ УПРАВЛІННЯ ПОРТ-ЛЕНДЛОРД:} УКРАЇНСЬКИЙ КОНТЕКСТ

\section{В.В. Шемаєв}

д.е.н., професор кафедри економічної теорії

Національний авіаційний університет, м. Київ

Л.М. Шемасва

к.е.н., доцент кафедри міжнародного бізнесу

Харківський начіональний економічний університет ім. С. Кузнеия, м. Харків

Анотація. 3 початком портової реформи в Україні була здійснена зміна моделі управління портовим сектором. Утворена у 2013 роичі Адміністрація морських портів України була наділена функиіями адміністративного та безпекового характеру. Суто комериійна діяльність залишилась у державних та приватних стивідорних компаній та морських терміналів. Зазначений розподіл функціоналу в морському порту наблизив вітчизняну систему управління до загальновідомої в краӥнах Північної Америки та Північно-Західної Свропи - «порт-лендлорд». Визначені в результаті дослідження аспекти, а саме контроль за земельними ділянками, юридичний статус Адміністрації морських портів України, наявність державних стивідорів та неврегульованість відносин з місцевою владою, не дозволяють класифікувати вітчизну модель в класичному розумінні «порту-лендлорду». Останнє вказує радше на гібридну модель в Украӥні з елементами «порт-лендлорд». Найбільш уразливим елементом в контексті моделі «портлендлорд» в Адміністрації морських портів України є брак механізму управління портовими територіями через наявність декількох типів землевласників - державних, місиевих та приватних суб'єктів. В статті запропоновано низку заходів, зокрема корпоратизація Адміністрації морських портів України, внесення змін до законодавства, новації в розподілі концесійного платежу, підтримка виходу держави з сегменту стивідорної діяльності, а також інвентаризаиія портових територій, реалізація яких може якісно наблизити украӥнську модель до практик управління портів Північно-Західної Свропи.

Ключові слова: портова галузь, портлендлорд, адміністрація морських портів України, моделі управління.

(C) Шемаєв В.В., Шемаєва Л.М., 2020
УДК 656.07:656.6

JEL L91, O21, R42

DOI 10.31375/2226-1915-2020-4-19-30

ПРИБЛИЖЕНИЕ

К МОДЕЛИ УПРАВЛЕНИЯ ПОРТЛЕНДЛОРДОВ: УКРАИНСКИЙ КОНТЕКСТ

\section{B.В. Шемаев}

д.э.н., профессор кафедры экономической теории Наииональный авиачионный университет, г. Киев Л.Н. Шемаева

к.э.н., доцент кафедры международного бизнеса

Харьковский начиональный экономический университет им. С. Кузнеца

Аннотация. С началом портовой рефор мы в Украине было произведено изменение модели управления портовым сектором. Созданная в 2013 году Администрачия морских портов Украины была наделена функииями административного характерам и безопасности (мореплавания, морской безопасности). Коммерческая деятельность осталась прерогативой государ ственных и частных стивидорных компаниях $u$ морских терминалов. Указанное распределение функиионала в морском порту приблизило отечественную систему управления к общеизвестной в странах Северной Америки и СевероЗападной Европы - «порт-лендлорд». Определенные в результате исследования аспекты, а именно контроль за земельными участками, юридический статус Администрачии морских портов Украины, наличие государственных стивидоров и неурегулированность отношений $c$ местными властями, не позволяют классифицировать отечественную модель в классическом понимании «порта-лендлорда». Последнее указывает скорее на гибридную модель в Украине с элементами «порт-лендлорд». Наиболее уязвимым элементом в контексте модели «портлендлорд» в Администрации морских портов Украины является нехватка механизма управления портовыми территориями из-за наличия нескольких типов землевладельиев - государственных, местных и частных субъектов. В статье предложен ряд мероприятий, в частности корпоратизаџия Администрации морских портов Украины, внесение изменений в законодательство, новации в распределении концессионного платежа, поддержка выхода государства из сегмента стивидорной деятельности, а также инвентаризация портовых территорий, реализация которых может качественно приблизить украинскую модель к практикам управления портов Северо-Западной Европьл.

Ключевые слова: портовая отрасль, порт-лендлорд, администрачия морских портов Украинь, модели управления. 
UDC 656.07:656.6

JEL L91, O21, R42

DOI 10.31375/2226-1915-2020-4-19-30

\title{
APPROXIMATION \\ TO A LANDLORD PORT MANAGEMENT MODEL: UKRAINIAN CONTEXT
}

\author{
Volodymyr Shemayev \\ Doctor of Economic Sciences, Professor of the Department of Economic Theory \\ shemayev.v.v@uz.gov.ua, ORCID ID: 0000-0001-5599-3941 \\ National Aviation University, Ukraine, Kyiv \\ Larysa Shemayeva \\ CEcon, Docent of the Department of International Business \\ lorafanasieva@gmail.com, ORCID ID: 0000-0001-9097-5191
}

Simon Kuznets Kharkiv National University of Economics

\begin{abstract}
Annotation. With the beginning of port reform in Ukraine, the model of port sector governance was changed. Established in 2013, the Ukrainian Sea Ports Authority was endowed with administrative, maritime safety and security functions. Purely commercial activities remained with public and private stevedoring companies and marine terminals. This distribution of functionality in seaports has brought the domestic governance model closer to the well-known in North America and North-Western Europe - landlord-port model. The aspects identified as a result of the study, namely control over land plots, legal status of the Ukrainian Sa Ports Authority, the presence of state stevedores, and unsettled relations with local authorities, do not allow to classify the domestic port governance model in the classical sense of landlord-port. The latter points rather to a hybrid model in Ukraine with some elements of landlord-port model, such as concessions, private participation in services etc. The most vulnerable element in the context of the portlandlord model at the Ukrainian Sea Ports Authority is the lack of a mechanism for managing port areas due to the presence of several types of landowners in a seaport including public, local and private entities. The article proposes a number of measures, including corporatization of the Ukrainian Sea Ports Authority, amendments to the legislation, innovations in the distribution of concession fees, support of the state's exit from the stevedoring activity segment in ports, as well as an inventory of port territories, the implementation of which can qualitatively bring the Ukrainian model closer to the port management practices of North-Western Europe. In addition, involvement of local authorities into activities of seaport councils as permanent members, andafter corporatization of Ukrainian Sea Ports Authority- to participate in pilot projects of joint ownership of autonomous port authorities (for example in the ports of Odessa and Mykolayiv) could facilitate a sustainable cooperation between a port and local governance.
\end{abstract}

Keywords: port industry, landlord port, Ukrainian Sea Ports Authority, management models.

Постановка проблеми. У 2013 році 3 прийняттям Закону України «Про морські порти України» [1] в Україні була розпочата реформа портової галузі. В результаті адміністративна та безпекова функції були виділені від суто комерційних. Перші відійшли до Адміністрації морських портів України (далі - АМПУ) 3 філіями в кожному морському порту, останні залишились у державних стивідорів - морських торговельних портах, набули офіційного визнання приватні суб'єкти господарювання в портах. Проте, відповідно до положень звіту Світового банку [2], прис- 
DEVELOPMENT OF MANAGEMENT

AND ENTREPRENEURSHIP METHODS ON TRANSPORT, № 4 (73), 2020
РОЗВИТОК МЕТОДІВ

УПРАВЛІННЯ ТА ГОСПОДАРЮВАННЯ

НА ТРАНСПОРТІ, № 4 (73), 2020 вяченому аналізу користування портовими територіями і рекомендацій щодо наближення до моделі управління «порт-лендлорд», вітчизняна модель управління портами не вкладається ні в одну 3 чотирьох класичних моделей в світі. Тобто Україна вже відійшла від суто державних портів - моделі, властивої для попередніх періодів у еволюції портової галузі, i має приватні термінали 3 операційними акваторіями. При цьому, в переважній більшості морські порти функціонують на звуженій в земельному функціоналі моделі «порт-лендлорд». Відповідно питання скоординованого та гармонійного розвитку існуючих та перспективних портових територій в Україні остаточно не вирішено.

Огляд останніх досліджень. Одним з перших досліджень за темою впровадження моделі «порт-лендлорд» в Україні здійснено А. Підгайним [3], який порівняв українську та латвійську системи управління портами та вказав на те, що у вітчизняній моделі державні органи влади навіть після реформи повністю контролюють питання фінансів, інвестицій, розподілу власності та землі, в той час, як портова влада, в особі АМПУ та іiі філій, займається операційними питаннями функціонування порту. Такі висновки знайшли підтвердження в рамках звіту Світового банку [2], в якому досліджено міжнародний досвід моделей управління в портовій галузі та поточна ситуація в управлінні портовою галуззю в Україні. Автори дослідження порівняли земельні відносини в портах України 3 міжнародними портами та надали ряд пропозицій щодо наближення до моделі управління «порт-лендлорд». Бельгійський вчений П. Верхувен [4] зазначає, що управління портами в цілому - це широке поняття, яке охоплює декілька вимірів, що можна використовувати сім різних груп параметрів при аналізі практик управління: (i) передача повноважень, (ii) корпоративне управління, (iii) операційний профіль, (iv) функціональна автономія, (v) функціональна активність, (vi) інвестиційна відповідальність та (vii) фінансова автономія. В іншій роботі П. Верхувен [5] зауважує, що сучасна адміністрація порту має бути «компанією 3 розвитку порту» i «інтегратором портового співтовариства», а не лише концентруватись на конвенційних функціях 3 організації безпеки мореплавства та формування тарифів та зборів за послуги. Узагальнений досвід та перспективи управлінських структур в портовій галузі представлено у роботі голландського вченого П. де Лангена [6]. У дослідженні О. Платонова [7] розкрито взаємозв'язок трансформації до моделі управління «порт-лендлорд» 3 розвитком мультимодальних перевезень. А. Селютін [8] дослідив модель «порт-лендлорд» крізь призму Національної транспортної стратегії. Юридичні особливості реформування портової галузі України підняті в роботах I. Бойко [9] та Є. Клюєвої [10]. Автори цієї статті також розглядали європейський досвід функціонування моделі «порт-лендлорд» в портах Антверпен і Роттердам [11]. У той же час у вітчизняних дослідженнях недостатньо розглянутим залишається питання щодо адаптації моделі «порт-лендлорд» до наявного статускво в портовій галузі, сформованого 3 
часів здобуття Україною незалежністю і закріпленою реформою галузі 2013 року.

Метою статті $\epsilon$ адаптація елементів моделі «порт-лендлорд» до українського контексту управління портовим сектором та визначення можливих шляхів іiі впровадження в Україні.

Основний матеріал дослідження. Еволюція управління в портовій галузі накопичила як мінімум чотири класичних моделі: державний порт, порт-інструмент, порт-лендлорд та приватний порт [2]. В класичному розумінні сутність моделі «порт-лендлорд» (від англ. - порт - «орендодавець/власник») полягає в наступному: адміністрація порту (англ. - port authority) виступає як регулюючий орган і як орендодавець (землі, акти- вів), тоді як комерційні портові операції (особливо обробка вантажів) здійснюються приватними компаніями [12]. Посібник з портової реформи [12] також зазначає, що портова інфраструктура здається в оренду приватним операторам зазвичай на платній основі (із розрахунку на 1 м. кв.), розмір якої пов'язаний із станом об'єкту та витратами на будівництво. Приватний суб'єкт господарювання в більшості випадків винаймає робочу силу, встановлює власне обладнання, забезпечує будівництво термінальної інфраструктури на взятій в оренду або концесії території/активах порту [12]. Яскравими прикладами моделі порт-лендлорд $\epsilon$ порти Північної Америки та Північно-Західної Європи, зокрема Роттердам, Антверпен, Лос-Анджелес (рис. 1).

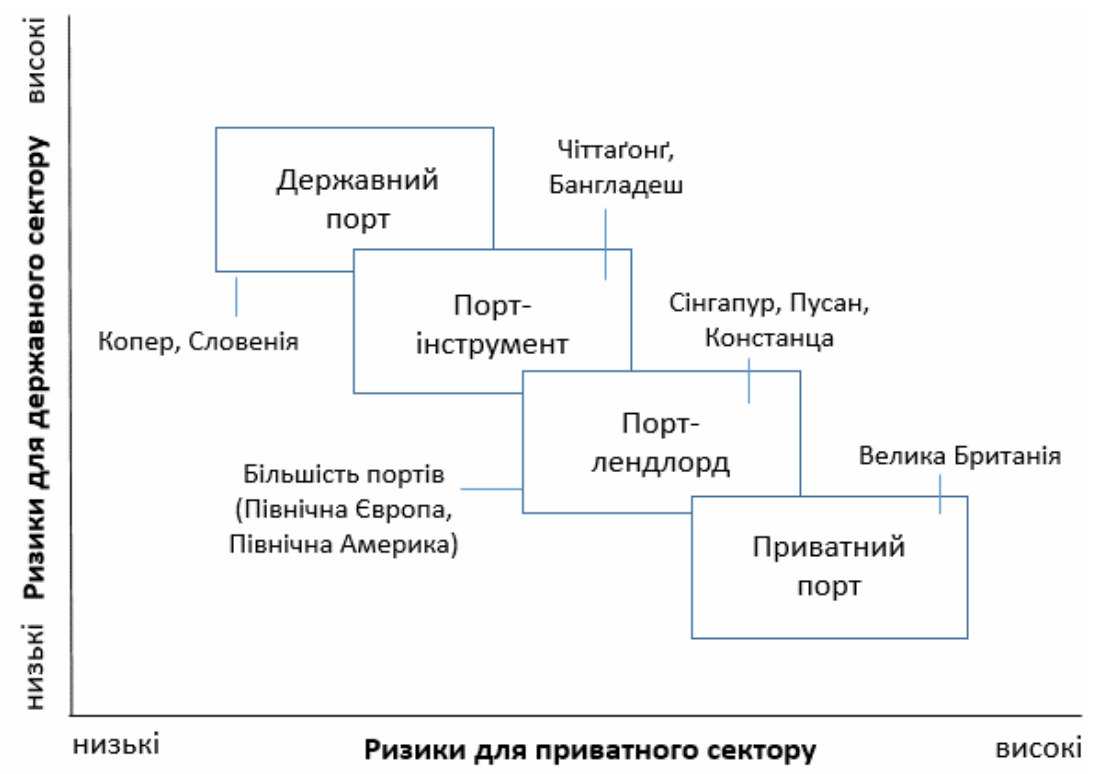

Рис.1. Основні моделі управління портами в міжнародній практиџі

Джерело: складено авторами на основі [2;13] 
DEVELOPMENT OF MANAGEMENT

AND ENTREPRENEURSHIP METHODS ON TRANSPORT, № 4 (73), 2020
РОЗВИТОК МЕТОДІВ

УПРАВЛІННЯ ТА ГОСПОДАРЮВАННЯ

НА ТРАНСПОРТІ, № 4 (73), 2020
Узагальнено розподіл функцій в порту за моделлю «порт-лендлорд» виглядає наступним чином:

- портова адміністрація, що має право власності або іншим чином (довірча власність від органів влади, оренда і тощо) здійснює контроль за користуванням портовими територіями, відповідає за планування i комплексний розвиток портів, організацію безпеки мореплавства;

- приватні портові оператори здійснюють стивідорну діяльність за договором концесії або оренди активів та/або землі 3 портовою адміністрацією;

- інші функції та процеси можуть здійснюватись як портовою адміністрацією, так і приватним сектором (лоцманія, буксирне супроводження, робота докерів тощо).

Слід зауважити, що в процесі інвестування в модернізацію і розвиток інфраструктури порту адміністрація морського порту на договірних умовах або через державно-приватне партнерство має право надавати приватним інвесторам об'єкти портової інфраструктури та земельні ділянки для будівництва, а інвестори мають право оперувати побудованими терміналами протягом строку за договором, після закінчення якого зазвичай можуть або продовжити (на певний період часу) дію договору, або повернути земельну ділянку разом 3 терміналом до власності адміністрації порту.

В Україні офіційне застосування терміну «порт-лендлорд» на державному рівні здійснено нещодавно. Зокрема, Національна транспортна стратегія України на період до 2030 року [14] містить завдання щодо вдосконалення законодавства з метою розвитку морських торговельних портів, перехід до європейської моделі управління «порт-лендлорд». Проте, документ не розкривав змісту цієї моделі. Спроба дати визначення цій моделі також міститься у проекті актуалізованої Стратегії розвитку морських портів України на період до 2038 року, яка наразі знаходиться на затвердженні в Кабінеті Міністрів України [15].

Наближення до моделі «портлендлорд» $є$ логічним продовженням реформи портової галузі, розпочатої в 2013 році, яка передбачала в тому числі вихід держави з сегменту стивідорного бізнесу шляхом передачі в управління державних активів - морських торговельних портів - професійним приватним операторам. У той же час реформа, зважаючи на локальний контекст, не повинна передбачати змін прав існуючих інвесторів щодо відносин власності на земельні ділянки в портах.

Певні кроки в напрямку наближення до моделі «порт-лендлорд» в Україні вже зроблені. Ще наприкінці 1990-х, початку 2000-х років в Одеському порту була запроваджена модель, при якій переробку вантажів здійснювали приватні компанії за договорами спільної діяльності/оренди 3 адміністрацією порту. Більше просування елементів моделі «порт-лендлорд» відбулось у 2013 році через утворення АМПУ 3 філіями - портовими адміністраціями, які не здійснюють перевалку вантажів і надають доступ учасникам ринку до стратегічної інфраструктури. Декілька морських портів вже отримали межі їх територій, зокрема Білгород-Дніст- 
DEVELOPMENT OF MANAGEMENT

AND ENTREPRENEURSHIP METHODS ON TRANSPORT, № 4 (73), 2020
РОЗВИТОК МЕТОДІВ

УПРАВЛІННЯ ТА ГОСПОДАРЮВАННЯ

НА ТРАНСПОРТІ, № 4 (73), 2020 ровський (у 2018 р.), Маріуполь (у 2019 р.), Скадовськ, Усть-Дунайськ, Чорноморськ (всі - у 2020 р.). Триває вихід держави $з$ сегменту стивідорної діяльності на умовах державно-приватного партнерства, в т.ч. концесійні конкурси в портах Ольвія і Херсон, в яких АМПУ буде вперше виступати в якості сторони договору на стороні Міністерства інфраструктури України 3 певним функціоналом 3 моніторингу та контролю та забезпечення експлуатаційного днопоглиблення. Міністерством інфраструктури України анонсовано підготовку до нових проектів концесії у портах Чорноморськ, Одеса, Бердянськ та Ізмаїл.

У процесі подальшої адаптації моделі «порт-лендлорд» до вітчизняної моделі управління портовим сектором необхідно обов'язково враховувати національний контекст. На відміну від портів Північно-Західної Свропи, у АМПУ та іiі філій бракує механізму управління і планування розвитком морських портів, спрямованого на ефективне користування територіями, гармонізацію інтересів державного, місцевого і приватного секторів, а також залучення інвестицій. Нижче наведені деякі аспекти, що характеризують український контекст впровадження моделі «порт-лендлорд», узагальнені в результаті цього дослідження.

Контроль за земельними ділянками. Території вітчизняних морських портів знаходяться в користуванні різних суб'єктів. Окрім передбаченого Законом України «Про морські порти України» плану розвитку відповідного порту, АМПУ не має повноважень щодо системного планування територій, оскільки АМПУ має в користуванні лише ті земельні ділянки, що знаходяться під власними активами підприємства [3]. Земельні ділянки під активами суб'єктів господарювання не мають юридичної афіліації з АМПУ. У таких портах як Чорноморськ, Одеса, Маріуполь, Рені, де територія морського порту фактично складається 3 території, що знаходиться в користуванні державного портового оператора - морського торговельного порту або іiі приватних орендарів, «лендлордом» де-факто мав би бути державний портовий оператор (хоча це i не притаманна функція портового оператору з точки зору забезпечення конкуренції порту), але зважаючи на особливості земельного законодавства - функцію «лендлорда» без прив'язки до плану розвитку порту виконує обласна державна адміністрація чи територіальна громада.

У випадку, коли земельна ділянка знаходиться у приватній власності або під контролем приватного суб'єкта господарювання - «лендлордом» де-факто стає приватний власник, що пропонує в оренду територію іншим - такі приклади можна спостерігати в портах Ольвія (термінал EVT), Миколаїв (Naval-парк), Південний (індустріальний парк iPark) без участі адміністрації морського порту. Таким чином прогнозована позиція зацікавлених сторін (стейкхолдерів) заключається в збереженні статус-кво i утриманні від посилення повноважень АМПУ щодо координації земельних ділянок. Для наближення до моделі «порт-лендлорд» в земельному аспекті АМПУ має укладати юридично-зобов' язуючі договори (наприклад довірчої власності, спільної 
DEVELOPMENT OF MANAGEMENT

AND ENTREPRENEURSHIP METHODS ON TRANSPORT, № 4 (73), 2020
РОЗВИТОК МЕТОДІВ

УПРАВЛІННЯ ТА ГОСПОДАРЮВАННЯ

НА ТРАНСПОРТІ, № 4 (73), 2020 діяльності, про співпрацю 3 власниками портових територій), які б задовольняли всі сторони договору і не погіршували поточний статус-кво власників (орендарів) земельних ділянок.

Наявність державних стивідорів. На відміну від більшості провідних портів світу, в Україні в кожному вітчизняному морському порту (окрім перших пілотних проєктів концесії в портах Ольвія та Херсон) продовжують функціонувати державні портові оператори - морські торговельні порти 3 високим показником фондомісткості. Ці державні підприємства мають на балансі активи i право користування земельними ділянками від органів місцевої влади. Функцію розпорядження їхніми активами виконує орган управління - Міністерство інфраструктури України, земельними ділянками - органи місцевої влади за погодженням з Міністерство інфраструктури України [3]. Тому передача в оренду або концесію їх активів чи земельних ділянок здійснюється без участі адміністрації морського порту - філії АМПУ. Сдиним рамковим документом для подальшого розвитку цього об'єкту (де-факто і де-юре переданого) $є$ план розвитку морського порту, що затверджується АМПУ і погоджується Міністерство інфраструктури України. Наближенням до моделі «порт-лендлорд» в цьому аспекті є подальший вихід держави 3 бізнесу 3 переробки вантажів шляхом державно-приватного партнерства, або в окремих випадках приватизації державних портових операторів із зобов'язаннями щодо збереження виду діяльності. У випадку державно-приватного партнерства
АМПУ для посилення своєї суб'єктності у розвитку портів має продовжувати підтримку концесійних ініціатив Міністерства інфраструктури України (з подальшою участі в концесійних договорах) i сконцентрувати свої зусилля на досягненні нормативних змін, які б дозволили їй отримувати частку концесійного платежу в результаті виконання певних зобов'язань за концесійним договором.

Юридичний статус АМПУ. Статус державного підприємства на відміну від приватного права не дозволяє самостійно передавати в оренду державне майно (отримуючи відповідну плату) або передавати в оренду чи концесію свої земельні ділянки, якщо такі активами не внесені до статуту акціонерного товариства. Передача нерухомого майна, в т.ч. причалів, в оренду здійснюється виключно через Фонд державного майна України, при цьому балансоутримувач підприємство отримує лише 30-відсоткову частку орендної плати. Тобто на сьогоднішній день, АМПУ позбавлене ролі «орендодавця/власника» (за виключенням рухомого майна), що прямо суперечить класичному визначенню моделі «порт-лендлорд». Корпоратизація або перетворення в акціонерне товариство із внесенням усіх активів цього державного підприємства, окрім акваторій портів та морських каналів, до статутного капіталу могло би змінити цю ситуацію.

Неврегульованість відносин 3 місиевою владою. На відміну від більшості портів Північно-Західної Європи 100-відсотковим власником АМПУ і державних портових операторів - морських торговельних портів є держава і скеровуються Міністер- 
DEVELOPMENT OF MANAGEMENT

AND ENTREPRENEURSHIP METHODS ON TRANSPORT, № 4 (73), 2020
РОЗВИТОК МЕТОДІВ

УПРАВЛІННЯ ТА ГОСПОДАРЮВАННЯ

НА ТРАНСПОРТІ, № 4 (73), 2020 ством інфраструктури України. Статус державного підприємства не передбачає участі місцевих органів влади в його повсякденному управлінні, розвитку такого підприємства або розподілі дивідендів/прибутку. У той же час місцеві органи влади є власниками або розпорядниками вільних земельних ділянок в морських портах та припортових територіях. Таким чином, наявна неузгодженість дій центральної i місцевої влади, які прагнуть управляти зазначеними активами і не передавати свої повноваження до адміністрації морського порту. Остання розглядається ними переважно як «один з суб'єктів господарювання» в морському порту. Недосконалою є система участі місцевих органів влади в процесах розвитку морських портів України, зокрема, що стосується відведення земель для розташування нових перевантажувальних потужностей, організації їх з'єднання 3 магістральними шляхами сполучення. Тому, навіть якщо на переданій в оренду місцевим органом влади земельній ділянці не відбувається проєкт розвитку морського терміналу, АМПУ не має юридичних інструментів щодо розірвання такого договору на противагу прямим договорам між портовою владою і інвестором, наприклад в порту Антверпен. Така ситуація ускладнює використання в Україні кращих світових практик управління портами. 3 метою подолання цієї проблеми, перспективним (після корпоратизації АМПУ) вважається залучення територіальних громад до акціонерного капіталу спільних підприємств - локальних адміністрацій морських портів.
У звіті Світового банку [2] відзначається, що подальшому розвитку портової галузі України на користь національної економіки, інтересів інвесторів i портових операторів, а також місцевого населення сприятиме наближення до моделі управління «порт-лендлорд». Вона позитивно зарекомендувала себе в міжнародній практиці і застосовується в більшості провідних портів Свропи і світу, таких як Роттердам, Антверпен, Сінгапур, Рига, Констанца, Гданськ.

Таким чином, можна зробити висновок про гібридний характер моделі управління портовим сектором України, який все ж таки тяжіє до о3нак моделі «порт-лендлорд». На шляху подальшого впровадження цієї моделі в Україні варто зосередитися на наступному:

- вдосконалення нормативноправової бази, в т.ч. внесення змін до Земельного кодексу України щодо статусу і особливостей відведення та користування земельними ділянками в порту;

- інвентаризація портових територій, в тому числі визначення та затвердження на нормативному рівні меж територій портів, і формування «земельного банку для перспективного розвитку»;

- поліпшення організації управління АМПУ шляхом корпоратизації підприємства (потребує ухвалення спеціалізованого закону), укрупнення філій в морських портах за мережевим принципом, придбання акціонерним товариством прав на земельні ділянки;

- досягнення нормативних змін на рівні держави, які б дозволили АМПУ (філії в порту) отримувати 
DEVELOPMENT OF MANAGEMENT

AND ENTREPRENEURSHIP METHODS ON TRANSPORT, № 4 (73), 2020 частку концесійного платежу в результаті виконання певних зобов'язань за концесійним договором;

- діалог зі стейкхолдерами власниками портових територій (земель промисловості або транспорту) та пошук формули юридично-зобов'язуючих договорів 3 ними, які б розширили інструментарій АМПУ 3 розвитку портів, не погіршуючи поточний статус-кво власників (орендарів) земельних ділянок;

- залучення органів місцевої влади до діяльності рад морських портів в якості постійних членів, а після корпоратизації АМПУ - до участі в пілотних проєктах спільного володіння окремими автономізованими портовими адміністраціями (наприклад у портах Одеса та Миколаїв, де переробку вантажів здійснюють виключно приватні суб'єкти господарювання та інфраструктура їх міст розташування активно експлуатується вантажним транспортом, що прямує до/з порту).

Висновки. Україна вже відійшла від суто державних портів - моделі, властивої попередніх періодів розвитку, і має фактично гібридну модель, яка містить окремі елементи моделі «порт-лендлорд». При цьому, в переважній більшості порти функціонують на звуженій в земельному функціоналі моделі «порт-лендлорд». Наближення до класичного розуміння моделі «порт-лендлорд» дозволить адміністраціям портів ефективно здійснювати функції портового планування і розвитку, забезпечить подальше підвищення конкурентного середовища в портовій галузі України, а отже - сприятиме ії якісному розвитку. У той же час для повноцінного продовження реформи, зважаючи на локальний контекст, не повинна передбачати змін прав існуючих інвесторів щодо відносин власності на земельні ділянки в портах, а навпаки пропонувати спільні зацікавленим сторонам (стейкхолдерам) вигоди від iï запровадження, що представляє науково-практичний інтерес для подальших досліджень. Успіх повноцінного впровадження моделі «порт-лендлорд» лежить в можливостях формуванні альянсів та спільному просуванні реформ на всіх рівнях прийняття рішень, в т.ч. законодавчому. Проте, навіть без законодавчих змін наявний достатній інструментарій для наближення сучасних практик розвитку портів 3 елементами моделі «лендлорд», зокрема вихід держави 3 сегменту стивідорної діяльності, цивілізовані проекти державно-приватного партнерства із залученням АМПУ, налагодження двостороннього діалогу адміністрацій портів 3 ключовими стейкхолдерам в портовій спільноті і місцевій владі.

\section{СПИСОК ЛІТЕРАТУРИ}

1. Закон Украӥни «Про морські порти України». Голос України - офіиійне видання від 13.06.2012. № 107.

2. World Bank (2020). Moving towards a landlord port management model. URL:http://uspa.gov.ua/en/investments/moving-towards-a-landlord-portmanagement-model. 
3. Подгайный А.П. Развитие морских портов Украины на основе внедрения обособленных портовых управлений. Електронний документ. URL: http://agreca.ua/wpcontent/uploads/2017/02/Brief_Landlord_Port_in_Ukraine_UA.pdf.

4. Verhoeven, P., Vanoutrive, T. A quantitative analysis of European port governance. Marit Econ Logist 14, 178-203 (2012).

5. Patrick Verhoeven (2010). A review of port authority functions: towards a renaissance?, Maritime Policy \& Management, 37:3, 247-270.

6. De Langen, P.W. (2020). Towards a Better Port Industry: Port Development, Management and Policy. Routledge.

7. Платонов О. І. Трансформація до моделі управління «порт-лендлорд» як запорука розвитку мультимодальних перевезень // Інвестииї: практика та досвід. 2020. № 13-14. C. 97-102.

8. Селютін А. Наиіональна транспортна стратегія крізь призму розвитку портів. Юридична газета online. 2017. №48 (598). Електронний документ. URL: https://yur-gazeta.com/publications/practice/transportnepravo/nacionalna-transportna-strategiya-kriz-prizmu-rozvitku-portiv.html.

9. Бойко I. Міжнародно-правове регулювання публічно-приватного партнерства, зарубіжний досвід та реформа портової галузі України // Підприємництво, господарство і право. № 8/2020. С. 323-329.

10. Клюєва $\epsilon$. Особливість адміністративно-правового забезпечення реформування системи управління морським портом в умовах інтеграиії України до Євросоюзу // Право та державне управління. №2(31), том 1. 2018. C. 120-124.

11. Шемаєв В. Від Антверпена до Роттердама: європейський досвід управління розвитком портової інфраструктури для морегосподарського комплексу Украӥни // Стратегічні пріоритети, 43(2), 2020. C. 120-128.

12. World Bank (2007) Port Reform Toolkit PPIAF, World Bank, 2nd Edition. URL: $\quad$ https://ppp.worldbank.org/public-private-partnership/library/portreform-toolkit-ppiaf-world-bank-2nd-edition.

13. Trends in EU ports governance 2016. Електронний документ. URL: https://www.espo.be/media/Trends_in_EU_ports_governance_2016_FINAL_V ERSION.pdf.

14. Наџіональна транспортна стратегія України на період до 2030 року, схвалена розпорядженням Кабінету Міністрів України від 30 травня 2018 p. № 430-p.

15. Проект оновленої Стратегї розвитку морських портів України на період до 2038 року. Електронний документ. URL: https:// mtu. gov. иа/ news/29415.html. 


\section{REFERENCES}

1. Zakon Ukrayiny "Pro mors'ki porty Ukrayiny» [Law of Ukraine "On Seaports of Ukraine"]. Holos Ukrayiny - ofitsiyne vydannya vid 13.06.2012 - Voice of Ukraine - official publication dated 13.06.2012. № 107 [in Ukrainian].

2. World Bank (2020). Moving towards a landlord port management model. Retrieved from: http://uspa.gov.ua/en/investments/moving-towards-a-landlordport-management-model.

3. Podgainy, Andrey (2015). Razvytye morskykh portov Ukrayny na osnove vnedrenyya obosoblennykh portovykh upravlenyy [Development of seaports of Ukraine on the basis of introduction of autonomous port authorities]. Retrieved from http://agreca.ua/wpcontent/uploads/2017/02/Brief_Landlord_Port_in_Ukraine_UA.pdf [in Russian].

4. Verhoeven, Patrick \& Vanoutrive, Thomas (2012). A quantitative analysis of European port governance. Marit Econ Logist 14, 178-203.

5. Patrick Verhoeven (2010) A review of port authority functions: towards a renaissance?, Maritime Policy \& Management, 37:3, pp. 247-270 [in English].

6. De Langen, P.W. (2020). Towards a Better Port Industry: Port Development, Management and Policy. Routledge [in English].

7. Platonov, Oleg (2020). Transformatsiya do modeli upravlinnya «portlendlord» yak zaporuka rozvytku mul'tymodal'nykh perevezen' [Transformation to the "port-landlord" management model as a guarantee of the development of multimodal transportation], Investytsiyi: praktyka ta dosvid - Investments: practice and experience, vol. 13-14, pp. 97-102 [in Ukrainian].

8. Selyutin, Andriy (2017). Natsional'na transportna stratehiya kriz' pryzmu rozvytku portiv [National transport strategy through the prism of port development.]. Yurydychna hazeta online. №48 (598). Retrieved from https://yur-gazeta.com/publications/practice/transportne-pravo/nacionalnatransportna-strategiya-kriz-prizmu-rozvitku-portiv.html [in Ukrainian].

9. Boyko, Inna (2020). Mizhnarodno-pravove rehulyuvannya publichnopryvatnoho partnerstva, zarubizhnyy dosvid ta reforma portovoyi haluzi Ukrayiny [International legal regulation of public-private partnership, foreign experience and reform of the port industry of Ukraine]. Pidpryyemnytstvo, hospodarstvo i parvo - Entrepreneurship, economy and law, pp. 323-329 [in Ukrainian].

10. Klyuyeva, Yevgeniia (2018). Osoblyvist' administratyvno-pravovoho zabezpechennya reformuvannya systemy upravlinnya mors'kym portom $v$ umovakh intehratsiyi Ukrayiny do Yevrosoyuzu [Peculiarity of administrative and legal support for reforming the seaport management system in the conditions of Ukraine's integration into the European Union]. Pravo ta derzhavne upravlinnya - Law and public administration. №2 (31), tom 1, pp. 120-124 [in Ukrainian]. 
11. Shemayev, Volodymyr (2020). Vid Antverpena do Rotterdama: yevropeys'kyy dosvid upravlinnya rozvytkom portovoyi infrastruktury dlya morehospodars'koho kompleksu Ukrayiny [From Antwerp to Rotterdam: European experience of port infrastructure management for Ukraine's maritime complex]. Stratehichni priorytety - Strategic priorities, 43(2), pp. 120-128 [in Ukrainian].

12. World Bank (2007). Port Reform Toolkit PPIAF, World Bank, 2nd Edition. Retrieved from https://ppp.worldbank.org/public-privatepartnership/library/port-reform-toolkit-ppiaf-world-bank-2nd-edition.

13. Trends in EU ports governance 2016. Електронний документ. Retrieved from https://www.espo.be/media/Trends_in_EU_ports_governance_2016_FINAL_V ERSION.pdf.

14. Natsional'na transportna stratehiya Ukrayiny na period do 2030 roku, skhvalena rozporyadzhennyam Kabinetu Ministriv Ukrayiny vid 30 travnya 2018 № 430-r. [National Transport Strategy of Ukraine for the period up to 2030, approved by the order of the Cabinet of Ministers of Ukraine on May 30, 2018, № 430-r.] [in Ukrainian].

15. Proyekt onovlenoyi Stratehiyi rozvytku mors'kykh portiv Ukrayiny na period do 2038 roku [Draft updated Strategy for the development of seaports of Ukraine for the period up to 2038]. Retrieved from https://mtu.gov.ua/news/29415.html [in Ukrainian].

Стаття надійшла до редакиії 24.11.2020

Посилання на статтю: Шемасв В.В., Шемасва Л.М. Наближення до моделі управління порт-лендлорд: український контекст // Розвиток методів управління та господарювання на транспорті: Зб. наук. праць, 2020. № 4 (73). 19-30. DOI 10.31375/22261915- 2020-4-19-30.

Article received 24.11.2020

Reference a JournalArtic: Shemayev, Volodymyr \& Shemayeva, Larysa. (2020). Approximation to a landlord port management model: Ukrainian context. Development of management and entrepreneurship methods on transport. 4 (73), 19-30. DOI 10.31375/2226-1915-2020-4-19-30. 